\title{
SCIENTIFIC EXPERIMENT FOCUSED AT PIGMENT DEGRADATION BY POLYVINYL CHLORIDE COMBUSTION IN SCIENCE EDUCATION
}

\author{
Zita Jenisová $(\mathbb{D}$, Jana Braniša $(\mathbb{D}$ \\ Constantine the Philosopher University in Nitra (Slovakia) \\ zjenisova@uk.f.sk,jbranisa@ukf.sk.
}

Received May 2018

Accepted April 2019

\section{Abstract}

The Environmental education navigates students towards environmentally friendly life style and securing a quality of life. The implementation of cross-section topics, including the Environmental education, into science classes, is possible through a variety of techniques. One of the least used methods is a real school experiment. The following paper presents the experiment, by which we simulate the combustion of PVC and observe the impact of combustion products on plants via UV-Vis spectrophotometry optical method. This method is suitable for qualification and analysis of vegetable pigments, i.e. chlorophylls, carotenoids, and anthocyanins. The experiment is integrated into the Techniques and Didactics of School Chemistry Experiments as a part of master degree course, which prepares students for the Chemistry teaching profession. The introduced experiment enables pedagogues to integrate the environmental education into teaching process and develop mathematical and science literacy of students in the Chemistry education.

Keywords - Environmental education, Photosynthetic pigments, Polyvinyl chloride, UV-Vis spectrophotometry.

\section{To cite this article:}

Jenisová, Z., \& Braniša, J. (2019). Scientific experiment focused at pigment degradation by polyvinyl chloride combustion in science education. Journal of Technology and Science Education, 9(3), 458-466. https://doi.org/10.3926/jotse.480

\section{Introduction}

Since the application of the school reform, the education in Slovakia has undergone some striking innovations. The changes are also reflected in the acceptance of the UNECE Strategy for Education for Sustainable Development (2005). The emphasis is given to the implementation of one of the crosssection topics - Environmental education. It is a problem-oriented interdisciplinary science that provides students with the opportunity to acquire the values, attitudes and skills that develop responsibility for the state of the environment and its protection (Liao, 2017; Mishra, 1993, UNESCO - UNEP, 1978).

The Environmental education is an approach towards environmentally friendly life style, securing a quality of life for the present and future generations and to the sustainable life of whole society. Novanská (2014) conducted research on the status of Environmental education in the educational process. Respondents stated that Environmental education had only rarely a status of an individual subject at Slovak schools. 
Most often, it is incorporated into other subjects through specific themes or projects. They also stated that it is rarely associated with the practical activities of students, for example, with a scientific experiment.

Teachers consider the following as disadvantages of integrating environmental education: insufficient time for implementation, lack of learning material, formalism, non-systemic approach, and disinterest of students in the Environmental education (Szarka \& Brestenská, 2014; Ganajová, Sotáková, \& Vargová, 2016). One of the possibilities of incorporating the cross-cutting topic into the teaching of Chemistry is experiment. Various experiments were developed for students to demonstrate the negative effects of pollutants on the environment. They are focused on the impact of acid rains on the plant growth (Fleet, Jones \& Petter, 1987), metal corrosion (www.rsc.org), lake acidification (Goss, 2003; Halstead, 1997), or erosion of stone monuments (Baedecker \& Reddy, 1993). This paper presents an experiment that highlights the negative impact of domestic plastic combustion, especially polyvinyl chloride (PVC), on plants. Students used spectrophotometry to quantify the content of photosynthetic pigments in plant samples. The workflow we used to monitor changes in chlorophyll and carotenoid concentrations was modified to be performed with the implementation of the school measurement system.

\section{Computer-Aided Experiment}

The expert studies on the implementation of information and communication technologies into education confirm that computers can be an effective tool for developing higher levels of critical thinking in students through their interactive and instant feedback (Roschelle, Pea, Hoadley, Gordin \& Means, 2000; Braniša \& Jenisová, 2015; Mokros \& Tinker, 1987). By combining modern technologies and school chemical experiment with the implementation of school measurement systems, the way opens for innovative methods of learning at all school levels. Students often criticize laboratory exercises, because the working procedures are strictly prescribed, impersonal, lacking opportunities for subjective decisionmaking and creativity. During lab exercises, they often re-use relatively insignificant skills (Meester \& Maskill, 1995). Students should handle different measurement tools, collect and analyze data in the light of previously and newly acquired knowledge. All the above-mentioned activities are presented by the described school experiment, in which we use the analytical optical UV-Vis spectrophotometry method implemented with the Vernier school measurement system (LabQuest 2) and spectrometer (Figure 1).
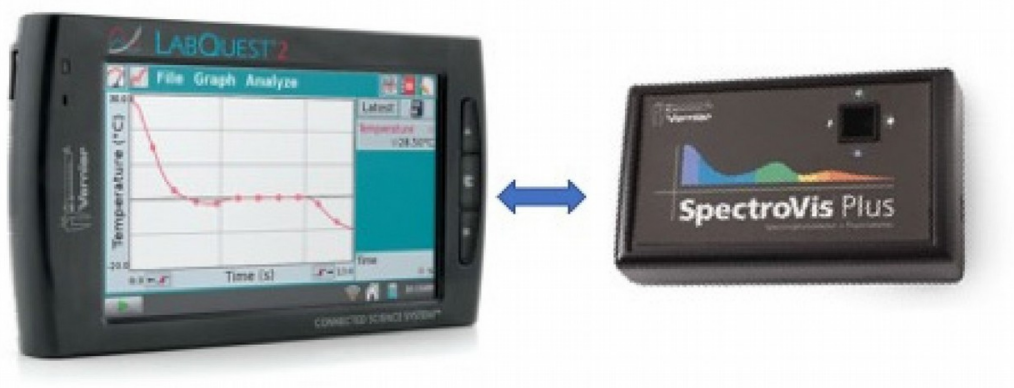

Figure 1. School measurement system (www.vernier.com)

The presented experiment may be implemented into lessons as a structured inquiry experiment, where the teacher presents students with a problem and working procedure. The experimentation leads students to the search for the relationship between variables and finding answers to the research questions. Through this approach, they acquire knowledge and create a supply of sensory experience for their further studies and lives (Scanlon, Anastopoulou, Kerawalla \& Mulholland, 2011; Kuhn, Black, Keselman \& Kaplan, 2000). 


\section{Natural Pigments}

Plants contain natural pigments (chlorophylls, carotenoids, anthocyanins) that are the source of their specific colouration and are one of the visual attributes for the evaluation of their quality. The composition of pigments in plants correlates with the photosynthetic potential of plants (Danks, Evans \& Whittaker, 1983; Gamon \& Surfus, 1999).

The selection of a suitable analytical method for the identification and quantification of pigments from the plant matrix depends on the characteristics of required data (Dudek, Strzelewicz, Krasowska, Rybak \& Turczyn, 2014). The most frequently used instrumental methodologies are the UV-VIS spectrophotometry, fluorescence spectroscopy and chromatography (Garber, Odendaal \& Carlson, 2013; West \& Rauch, 1994; Ayudhya, Posey, Tyus \& Dingra, 2015; Johnston, Scaggs, Mallory, Haskett, Warner, Brown, et al., 2013; Galloway, Bretz \& Novak, 2015; Rollins, 1963; Lalitha, 1994; Kimbrough, 1992; Valverde, This \& Vignolle, 2007). Each of these techniques has several advantages; however, the UV-Vis spectrophotometry is the most suitable for the routine determination of the pigment concentration in the extract from the mixed plant samples, as it generally does not require complicated separation and purification processes. The method is limited in cases where the absorption bands of more concurrently present pigments overlap, therefore only the dominant pigments present in the mixture may be determined by this method. The mathematical processing of spectral data extends the analysis to mixture extracts.

Chlorophyll $a(\mathrm{Chl}$ a) may be identified by two absorption maxima, at wavelengths of 428 and $661 \mathrm{~nm}$, Chlorophyll $b(\mathrm{Chl} b)$ at 453 and $642 \mathrm{~nm}$. These absorption peaks are slightly shifted depending on the use of extraction reagents. The carotenoid absorption spectrum in the visible range is generally a wide band of three maxima in the range from 400 to $500 \mathrm{~nm}$ (Lichtenthaler \& Buschmann, 2001; Juhász \& Szarka, 2015). For the calculation of the pigment concentration in the extract, we use a set of equations involving the readout of the respective absorbance Pessarakli (2010).

\section{Experimental Procedure}

For the experiment, students must obtain any green plants samples, from which they extract pigments with acetone-water mixture (4:1). Every plant sample is divided into two equal parts; one is kept as a control sample. The apparatus consists of a combustion tube and two bubblers. The first bubbler contains the plant samples and the second contains $1 \%$ solution of silver nitrate. After the construction of apparatus (Figure 2), the combustion tube with PVC (about $2-3$ grams) is slowly heated by gas burner for approximately 2 minutes. In order to speed up the gas flow through the receptacles, it is suitable to connect the whole apparatus to a vacuum pump. For the control sample, the filter paper is burned in the tube under identical conditions.

Subsequently, the control sample and the sample exposed to the $\mathrm{HCl}$ released from PVC are homogenized in a mortar, weighed (weighed sample is approximately $0.1 \mathrm{~g}$ ) and after addition of the extraction solvent (20 $\mathrm{ml}$ of solvent), they are extracted for 20 minutes.

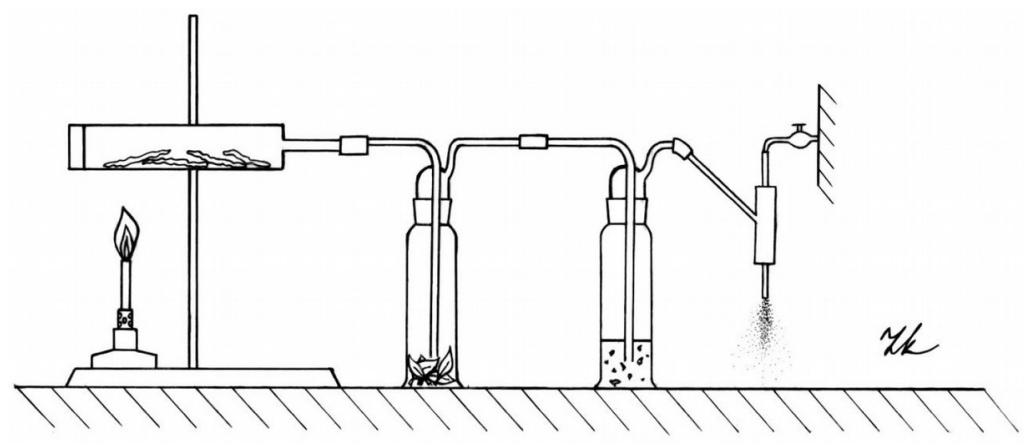

Figure 2. Apparatus schematic (Kričková, 2017) 
The extraction can be made more effective by shaking of samples or with homogenizers. When the extraction is complete, the mixture is filtered. Students measure the spectrum of filtrates in the range of wavelengths from 360 to $780 \mathrm{~nm}$ and take the reading of the absorption maxima at $663.6 \mathrm{~nm}$ for Chl $a$, $646.6 \mathrm{~nm}$ for $\mathrm{Chl} b$, and $440.5 \mathrm{~nm}$ for carotenoids. Contents of $\mathrm{Chl} a$, Chl $b$ and carotenoids are calculated from the following equations Yang, Chang, Yin \& Huang (1998):

Chlorophyll $a(\mu \mathrm{g} / \mathrm{ml})=12.25 \cdot \mathrm{A}_{663,6}-2.25 \cdot \mathrm{A}_{646,6}$

Chlorophyll $b(\mu \mathrm{g} / \mathrm{ml})=20.31 . \mathrm{A}_{646,6}-4.91 \cdot \mathrm{A}_{663,6}$

Carotenoids $(\mu \mathrm{g} / \mathrm{ml})=4.69 . \mathrm{A}_{440,5}-0.267\left(17.76 . \mathrm{A}_{646,6}-7.13 . \mathrm{A}_{663,6}\right)$

where $\mathrm{A}=$ absorbance for responding wavelength.

The same procedure is performed for each sample. The results are expressed as micrograms per 100 grams fresh weight of sample.

Finally, students may calculate the pigment content in the analyzed samples of leaves, but also to compare the percentage loss of pigments in the samples exposed to gases produced during the burning of PVC. The data obtained by one group of students is shown in Figure 3.

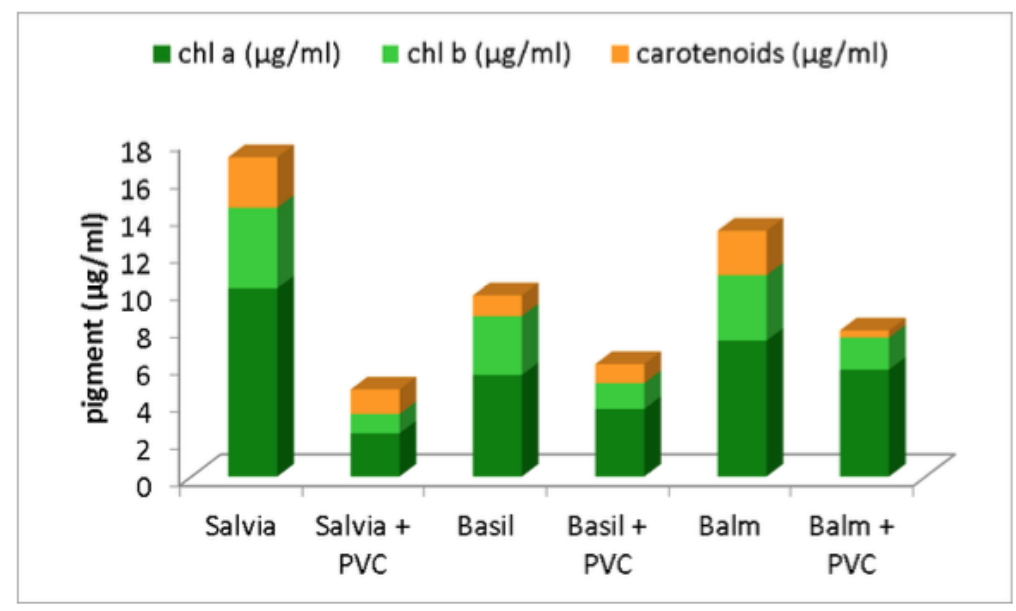

Figure 3. The chlorophyll and carotenoid content of herbs extract

\section{Results and Discussion}

Students obtain the most accurate results, if the measured absorbance of the samples is in the range from 0.1 to 1.0. Therefore, it is necessary that the first sample is the control one, so the students chose the optimal ratio of sample weight and extraction solvent volume. The approximate sample weight for these green samples is $0.1 \mathrm{~g}$ for $20 \mathrm{ml}$ of extraction solvent. The exact definition of sample weight and extraction solvent in the working method is problematic due to the fact, that the pigment content in the plant sample (i.e. the resulting colour of the extraction solution) is affected by several factors, e.g. extraction time, variety of crops, level of maturity and origin of plant sample in regard to geographical conditions.

The PVC is subject to thermal degradation at low temperatures (approx. $100{ }^{\circ} \mathrm{C}$ ) and evolves hydrogen chloride. In order for the degradation of the pigment to occur, it is sufficient that the combustion tube is heated briefly. In our experiment, the combustion tube was heated for 2 minutes and the leaves sample was kept in the bubbler for 3 more minutes, but without heating. On the plant samples damaged by hydrogen chloride, it is visible at first sight, that there was a change of colour. The leaves have brown spots; they lose their lush green colour and take a yellowish-brown tone. 


\subsection{Explanation}

The loss of green colour of chlorophyll during the burning of PVC is mainly caused by the replacement of the magnesium cation in the chlorophyll skeleton by two hydrogen ions and the green chlorophyll is converted to olive-brown pheophytin (Figure 4).

The white precipitate of $\mathrm{AgCl}$ formed in the second bubbler indicates that hydrogen chloride is released into the air by the burning of PVC.

\section{Chlorophyll a}

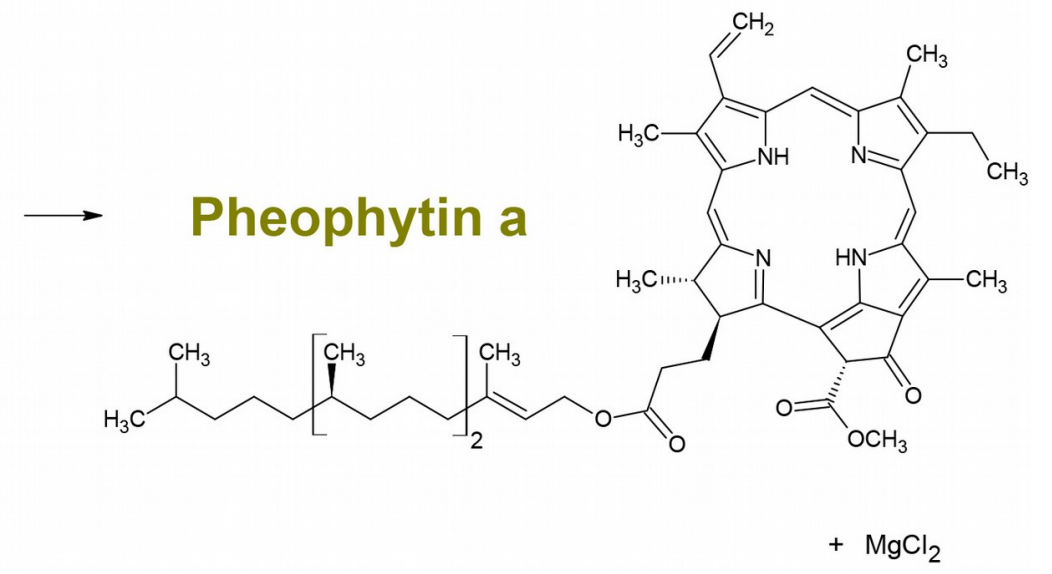<smiles>COC(=O)[C@H]1C(=O)C2=C(C)CN(C)C2=C1C1=[N+](C)C[C@H](C)[C@@H]1CCC(=O)OC/C=C(\C)CCCC(C)CCCC(C)C</smiles>

Figure 4. Reaction scheme of hydrogen chloride effect from burned PVC on chlorophyll structure

\section{Organization of Laboratory Experiment}

In the exercises, students work in two-person teams and each subgroup of students follows the instructions listed in the worksheet. At the start of experimental work, students divide roles in the team. Generally, while one works with the plant sample and exposes it to the gases produced from the PVC burning, the other homogenizes the samples, extracts and measures their spectra. As the students have a relatively short time for the experiment performance, laboratory exercises take only 90 minutes, the calculations and the evaluation of experimental data are done at home. All groups of students are able to complete the experiment in the given time.

The presented laboratory exercise was focused on the numerical solution by using mathematical formulas. Students were able to draw conclusions from the experiment without the algorithmic solution of the problem. This method is simpler and less time consuming. Students correctly solved the problem if they assigned the lowest pigment content to the graph with the lowest absorbance values (sample exposed to PVC). Conversely, where the dependence of absorbance from wavelength was greatest, the sample had the highest pigment content (control sample). It is up to the teacher to choose the approach to evaluate the experimental data. 


\section{Alternative Approaches to this Laboratory Experiment}

The experiment procedure of may be modified in several ways:

1. The combustion of PVC in the experiment procedure may be replaced with hydrochloric acid solution. By forming a closed system, the plant sample is directly exposed to gaseous hydrogen chloride (Figure 5).

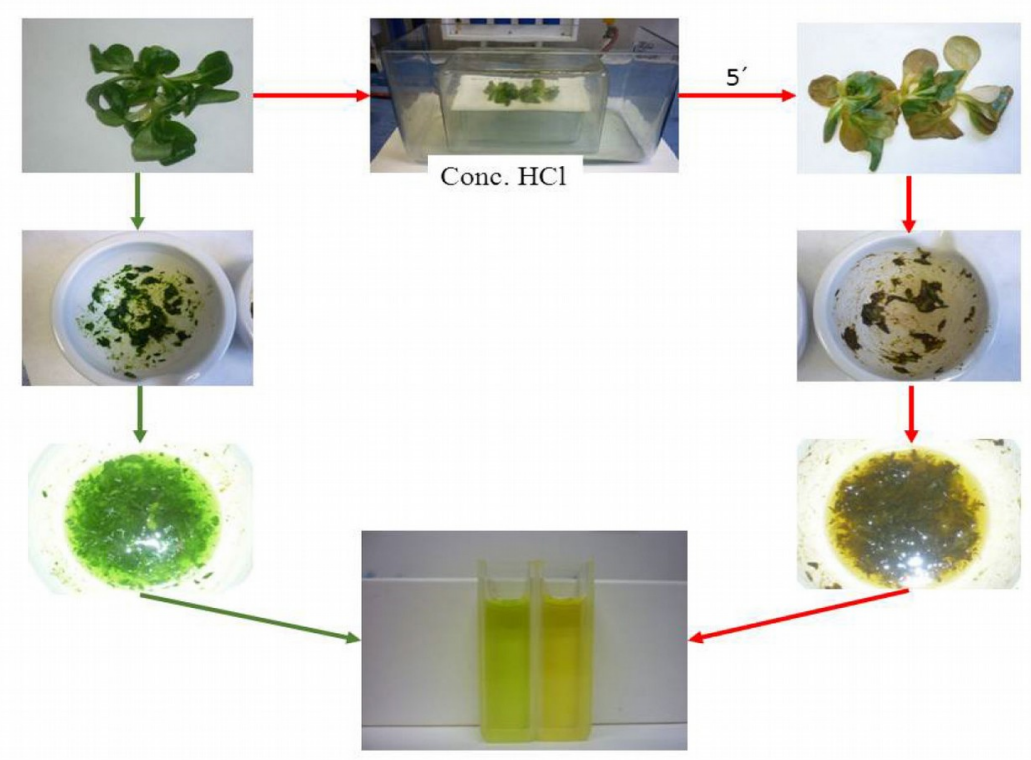

Figure 5. Alternative of experiment

2. An alternative optical method for the quantitative determination of pigments is the fluorescence method. It is much more sensitive and does not require a complicated pre-preparation of the sample. It allows the analysis of complex multi-component samples. This method may be implemented by using a computer-based laboratory and a SpectroVis Plus measuring sensor that also allows fluorescence measurement of substances.

3. The working procedure of the experiment may be extended to other plant samples and different extraction times. Furthermore, students may modify the procedure so that for the extraction of the dye they use alternative organic solvents in order to compare the effect of solvent polarity on the efficiency of extraction.

\section{Conclusion}

The practical benefit of the experiment is to improve students' attitudes towards the environment, the development of mathematical competence - working with graphical data, comparing graphic representations, calculation of the amount of pigment in the samples, but the student is led to an exact work - weighing, homogenization, preparation of extraction solution. The comparison of the absorption spectra develops in students the understanding of the relationship between the structure and properties of substances - the change in the structure of molecules causes the changes in the absorption spectrum of substances. In addition to the abovementioned knowledge and skills, the attitude towards the correct method of dealing with polymer waste and the awareness of its improper disposal threat is formed. Environmental education represents a poorly established pedagogical discipline in Slovakia, which is not a separate subject in the educational system (at primary and secondary level of education). Teachers, however, are expected to implement environmental education into their lessons as one of the cross-curricular themes. For this reason, universities are an important and often primary mediator of the environmental awareness. To train future teachers in responsible behavior and to engage them in solving environmental problems and their implementation in the teaching of their subjects, they must acquire 
knowledge, skills, and often a relationship to the subject of learning. They must gain the necessary experience to be ready to implement this cross-curricular theme. However, it requires further improvement and continuous search for new, interesting approaches to addressing these educational and learning problems. In conclusion, we may state that the Environmental education has an important place in education. It is involved in shaping and developing key competencies of students, particularly in the field of attitudes and values. However, its implementation requires a further improvement and constant search for approaches to address educational and learning challenges.

\section{Declaration of Conflicting Interests}

The authors declared no potential conflicts of interest with respect to the research, authorship, and/or publication of this article.

\section{Funding}

This work was supported by the Slovak Research and Development Agency under the contract No. APVV-15-0368. The authors thank Peter Godovič for spelling and grammar corrections.

\section{References}

Ayudhya, T.I.N., Posey, F.T., Tyus, J.C., \& Dingra N.N. (2015). Using a Microscale Approach To Rapidly Separate and Characterize Three Photosynthetic Pigment Species from Fern. Journal of Chemical Education, 92(5), 920-923. https://doi.org/10.1021/ed500344c

Baedecker, P.A., \& Reddy, M.M (1993). The Erosion of Carbonate Stone by Acid Rain: Laboratory and Field Investigations. Journal of Chemical Education, 70(2), 104. https://doi.org/10.1021/ed070p104

Braniša, J., \& Jenisová, Z. (2015). The use of computer aided experiment in enhancing the ability of students to understand the graphical presentation of chemical processes. Procedia - Social and Behavioral Sciences: WCES-2015. 2229-2235. https://doi.org/10.1016/j.sbspro.2015.07.364

Danks, S.M., Evans, E.H., \& Whittaker, P.A. (1983). Structure function and assembly. Photosynthetic Systems (162). Wiley.

Dudek, G., Strzelewicz, A., Krasowska, M., Rybak, A., \& Turczyn, R. (2014). A spectrophotometric method for plant pigments determination and herbs classification. Chemical Papers, 68(5), 579-583. https://doi.org/10.2478/s11696-013-0502-x

Fleet, G., Jones, C. \& Petter, D. (1987). Acid rain in the classroom: A student research project. Journal of Biological Education, 21(3), 156-158. https://doi.org/10.1080/00219266.1987.9654887

Galloway, K.R., Bretz, S.L., \& Novak, M. (2015). Paper Chromatography and UV-Vis Spectroscopy To Characterize Anthocyanins and Investigate Antioxidant Properties in the Organic Teaching Laboratory. Journal of Chemical Education, 92(1), 183-188. https://doi.org/10.1021/ed400520n

Gamon, J.A., \& Surfus, J.S. (1999). Assessing leaf pigment content and activity with a reflectometer. New Phytologist, 143(1), 105-117. https://doi.org/10.1046/j.1469-8137.1999.00424.x

Ganajová, M., Sotáková, I., \& Vargová, Z. (2016). Od akademického spôsobu výučby k bádatel'sky orientovanej výučbe - Inovácia výučby praktických cvičení z chémie na Prírodovedeckej fakulte UPJŠ v Košiciach Eruditio. Educatio, 11(2), 45-51.

Garber, C.A.K, Odendaal, A.Y., \& Carlson, A.E.E. (2013). Plant Pigment Identification: A Classroom and Outreach Activity. Journal of Chemical Education, 90(6), 755-759. https://doi.org/10.1021/ed200823t

Goss, L.M. (2003). A Demonstration of Acid Rain and Lake Acidification: Wet Deposition of Sulfur Dioxide. Journal of Chemical Education, 80(1), 39. https://doi.org/10.1021/ed080p39

Halstead, J.A. (1997). Rain, Lakes, Streams: Investigating Acidity and Buffering Capacity in the Environment. Journal of Chemical Education, 74(12), 1456. https://doi.org/10.1021/ed074p1390 
Johnston, A., Scaggs, J., Mallory, C., Haskett, A., Warner, D., Brown, E., et al. (2013) A Green Approach To Separate Spinach Pigments by Column Chromatography. Journal of Chemical Education, 90(6), 796-798. https://doi.org/10.1021/ed300315z

Juhász, G., \& Szarka. K. (2015). Spektroskopické vlastnosti molekúl - výučba pomocou IKT. Inovácia a kreativita vo vzdelávaní a vede - Sekcie ekonomických vied a IKT. 212-217.

Kimbrough, D.R. (1992). Supermarket column chromatography of leaf pigments. Journal of Chemical Education, 69(12), 987. https://doi.org/10.1021/ed069p987

Kuhn, D., Black, J., Keselman, A., \& Kaplan, D. (2000). The development of cognitive skills to support inquiry learning. Cognition and Instruction, 18, 495-523. https://doi.org/10.1207/S1532690XCI1804_3

Lalitha, N. (1994). Chromatographic Separation of Plant Pigments Using Sand as the Adsorbant: An Inexpensive Chromatographic Technique. Journal of Chemical Education, 71(5), 432. https://doi.org/10.1021/ed071p432

Liao, W.W. (2017). A Study on the Correlations among Environmental Education, Environment-Friendly Product Development, and Green Innovation Capability in an Enterprise. EURASLA Journal of Mathematics Science and Technology Education, 13(8), 5435-5444. https://doi.org/10.12973/eurasia.2017.00841a

Lichtenthaler, H.K. \& Buschmann, C. (2001). UNIT F4.3 Chlorophylls and Carotenoids: Measurement and Characterization by UV-VIS Spectroscopy. Current Protocols in Food Analytical Chemistry. https://doi.org/10.1002/0471142913.faf0403s01

Meester, M.A.M., \& Maskill, R. (1995). First year chemistry practicals at university in England and Wales: aims and the scientific level of the experiments. International Journal of Science Education, 17, 575-588. https://doi.org/10.1080/0950069950170503

Mishra, V.S. (1993). Environmental education and awareness: The Indian environment perspective. Scavenger, 24(1), 9 .

Mokros, J.R., \& Tinker, R.F. (1987). The Impact of Microcomputer-Based Labs on Children's Ability to Interpret Graphs. Journal of Research in Science Teaching, 24, 369-383. https://doi.org/10.1002/tea.3660240408

Novanská, V. (2014). Environmentálna výchova ako prierezová téma v edukačnom procese na slovenských základných školách. Biológia, ekologia, chémia, 18(1), 2-8.

Pessarakli, M. (2010). Handbook of plant and crop stress. Boca Raton, FL, USA: CRC Press.

Rollins, C. (1963). Thin layer chromatographic separation of leaf pigments: A rapid demonstration. Journal of Chemical Education, 40(1), 32. https://doi.org/10.1021/ed040p32

Roschelle, J.M., Pea, R.D., Hoadley, C.M., Gordin, D.N., \& Means, B.M. (2000). Changing How and What Children Learn in School with Computer-Based Technologies. The Future of Children and Computer Technology, 10(2), 76-101. https://doi.org/10.2307/1602690

Scanlon, E., Anastopoulou, S., Kerawalla, L., \& Mulholland, P. (2011). How technology resources can be used to represent personal inquiry and support students' understanding of it across contexts. Journal of Computer Assisted Learning, 27, 516-529. https://doi.org/10.1111/j.1365-2729.2011.00414.x

Szarka, K., \& Brestenská, B. (2014). Prostriedky rozvíjajúceho hodnotenia vo vyučovaní prírodovedných predmetov. Inovácie a trendy v prírodovednom vadelávani, 131-158.

UNECE (2005). UNECE Strategy for Education for Sustainable Development, adopted at the High-level meeting. High-level meeting of Environment and Education Ministries (Vilnius, 17-18 March 2005). Available at: https://www.unece.org/fileadmin/DAM/env/documents/2005/cep/ac.13/cep.ac.13.2005.3.rev.1.e.pdf

UNESCO/UNEP (1978). The Tbilisi Declaration: Toward and Action Plan. A Report on the Tbilisi Intergovernmental Conference on Environmental Education. Washington, DC. US Government Printing Office. 
Valverde, J.; This, H., \& Vignolle, M. (2007). Quantitative Determination of Photosynthetic Pigments in Green Beans Using Thin-Layer Chromatography and a Flatbed Scanner as Densitometer. Journal of Chemical Education, 84(9), 1505. https://doi.org/10.1021/ed084p1505

West, K.J., \& Rauch, P. (1994). Microscale Column Chromatographic Isolation of a Red Pigment from Paprika. Journal of Chemical Education, 71(3), A59. https://doi.org/10.1021/ed071pA59

Yang, C.M., Chang, K.W., Yin, M.H., \& Huang, H.M. (1998). Methods for the determination of the chlorophylls and their derivatives. Taiwania, 43(2), 116-122.

Published by OmniaScience (www.omniascience.com)

Journal of Technology and Science Education, 2019 (www.jotse.org)

\section{(c) (i) (8)}

Article's contents are provided on an Attribution-Non Commercial 4.0 Creative commons International License. Readers are allowed to copy, distribute and communicate article's contents, provided the author's and JOTSE journal's names are included. It must not be used for commercial purposes. To see the complete licence contents, please visit https://creativecommons.org/licenses/by-nc/4.0/. 